\title{
Inherited Space - Third Millennium Political and Cultural Landscape
}

The third millennium political and cultural landscape of Syria and Upper Mesopotamia, territories where the state of Mittani ruled from the I6th century BC, was little known until just over thirty years ago. This was because very few centres had been excavated and, due to the scarcity of epigraphic and archaeological data, its history was hardly known. Beginning in the early eighties our knowledge increased enormously, thanks to the excavations in the numerous tells of Syrian Jazirah and to the discoveries of the Ebla, Tall Beydar and Tall Mozan written sources. ${ }^{\mathrm{I}}$

The geographical horizon of the Ebla texts is wide; they acquaint us with the political and cultural situation in the vast region of Syria and Upper Mesopotamia in the EDIIIb period of the third millennium.

* Universtà di Roma, La Sapienza. I would like to thank the organizers of this Topoi workshop for the wonderful way in which they organized the symposium. It was very important to have the opportunity to know all the texts of the participants before the workshop to prepare for the discussion, which was very fruitful and from which I learned a lot. The following abbreviations are used: ARET = Archivi Reali di Ebla. Testi; ARES = Archivi Reali di Ebla. Studi; MEE=Materiali Epigrafici di Ebla.

I For these regions during the Akkadian period and that of the Third Dynasty of Ur see the exhaustive article by Sallaberger 2007, 4I7-456. I will just add some observations on Syria and Upper Mesopotamia during ED IIIb, especially with the data furnished by the Ebla texts. It must be noted that some historians consider the river Euphrates the more important of the two rivers in the history of ancient Mesopotamia. It was sometimes a barrier or a frontier, but mainly the great commercial route between Lower Mesopotamia, Syria and the Mediterranean. During the first years studying relations between the kingdom of Ebla and the important powers of the period, after Gelb outlined in many studies a Kiš civilization and its contacts with Ebla, some scholars (For the bibliography see ARES II, 328-330; Bonechi I993, I59) discussed whether the city of Kiš, mentioned frequently in the Ebla texts, was the Mesopotamian one or not. For example, Pomponio supposed that the city of Kiš had to be closer to Ebla because it was impossible for the kingdom of Ebla to have direct relationships with Kiš in Mesopotamia; the city of Mari on the middle Euphrates would have stopped any attempt by Ebla to reach Kiš. This idea was based on a misunderstanding of the great importance of the region of Upper Mesopotamia in the Early Bronze IV period; the road to Kis followed by the Eblaites was through Nagar, to the Tigris and then down to central Mesopotamia. But in the early eighties the great role and importance of Upper Mesopotamia at the time of the Ebla texts was not yet evident, even if it was known that centres like Assur and Niniveh (documented for that period mostly by archaeological data) had some importance in the third millennium. The Old Akkadian texts from Gasur, like those (older) of Šuruppak (Fara), were largely forgotten by scholars and only the discovery of the Ebla texts and the publication of the Abu Salābikh texts permitted a renewal of interest and renewed study. Now we have two reviews that bring us immediately to those regions: Amurru and Subartu. 


\section{Political landscape at the time of the Ebla archives}

The reconstruction of the geographical horizon of the Eblaite kingdom (including its constituent, confederate and conquered space) in the period documented by the royal archives (XXIV cent. BC) is a forbidding and ambitious task, and study on this topic will still be "in progress" for a very long time. ${ }^{2}$

The geopolitical situation is documented by administrative texts and by some letters of foreign kings with whom the kings of Ebla had economic/political/diplomatic relations and by the text of an international treaty concerning Ebla's trade with the city of Abarsal, which had its own commercial network. ${ }^{3}$

Other evidence for the relations of the Eblaite kingdom with foreign countries and of long distance trade comes from archaeological sources. 4

From all the texts it clearly emerges that the geographical horizon of the Eblaite kingdom was very similar to that of the Mittani kingdom. It included kingdoms far from Ebla, such as Kiš in central Mesopotamia, Hamazi east of the Tigris, Aššur (very probably) on the Tigris, Gasur (possibly) east of the Tigris, Nagar in Upper Mesopotamia, Mari on the Euphrates, Armi/Armanum on the Euphrates, possibly Tall Bazi-Banat 5 and Harran to the north, in Anatolia. Some (a few) texts quote Mesopotamian Akšak and Adab too.

- Hamazi: The kingdom of Hamazi, already known thanks to its mention in the Sumerian King List, in a region probably East of the Tigris, is well documented by the text ARET XIII 3. From the text it is evident that equids-BAR.AN came from the region of Ha-

2 We are studying all the topics suggested when organizing this workshop. The constituent space of the Eblaite kingdom is now the subject of a European research project "Ebla chora", with the aim of studying the villages and the towns under the direct control of Ebla, i.e. the towns where the kings and the viziers of Ebla had palaces; the towns of some sanctuaries of the god Adabal as Luban and Arugadu; the three sanctuaries of the goddess Išhara (very probably in the territory of the Eblaite kingdom); the towns visited in the ritual of renewal of royalty; some cities (probably Eblaite emporium, karum) such as Anmašu, Mabarra, Madu, Arugadu and others where textiles are often delivered. The treaty between Ebla and Abarsal (ARET XIII 5) shows that within its commercial network Ebla possessed and controlled many karum, or commercial bases. These centres, where foreign kings and various personages received textiles, need to be studied, but it is difficult to put cities and villages under the direct control of Ebla on a map because the location of almost all these cities remain unknown; furthermore, the 3 rd millennium names of tells close to Tall Mardikh (Ebla) like Tall Afis and Tall Tuqan (Nirar?), inhabited at the time of the Ebla archives, are also unknown. For the Ebla chora see Biga 2013, 259-267. For the possible identification of Tall Tuqan with the capital of the kingdom of Nirar see Biga - Capomacchia 20I2 (in print). To reconstruct the confederate space of the Ebla kingdom we are studying the Eblaite political and commercial network, see for example Biga 2008, 289-3II; Biga (in print). For the conquered space, see some studies on the wars of Ebla, Biga 2003, 79-87; Archi - Biga 2003, I-44; Biga 2008, 3II-33I; Biga 20Iob, 39-57.

3 For these letters and the treaty see ARET XIII.

4 For the presence of lapislazuli from the area of Afganistan in Palace G of Ebla see Pinnock I988, IO7-IIo; Pinnock 2006, 347-357; for the relationships of the Eblaite kingdom with foreign countries including Egypt see Scandone Matthiae I979, 33-43; Scandone Matthiae I997, 4I5-427; Biga 2008, 289-334; Biga 20I0a, 23-40; Biga 2010b, 39-57.

5 For the proposed identification of Tall Bazi-Banat with Armi of the Ebla texts see Otto 2006a, I-26; Otto - Biga 20I0, 48I-494. 
mazi to Ebla while precious woods from the Syrian region, such as boxwood, and objects made of wood were sent via Ebla. ${ }^{6}$

- Aššur: It has been shown that the city of Abarsal, which made a treaty with Ebla (ARET XIII 5), is not Assur, but must be located on a river, possibly the Euphrates or one of its affluents. Archaeological data prove that Aššur at the time of the Ebla archives was an important city. In the oldest Ebla texts there is no mention of toponyms that can be considered a written version of the name of the city of Aššur. But in one late text concerning Ebla's military campaign against Mari a reference to Aššur is quite possible. In text 75.G.2250, in which many cities are mentioned for the first time, textiles are registered as having been given to people of the city of $A-{ }^{-s} u-r u_{12}{ }^{k i}$, some of whom were going to Kišs, to people of Ebla going to $A-\bar{s} u-r u_{12}{ }^{k i}$ and to people of Mari going to $A$-šsu-ru ${ }_{12}{ }^{k i}{ }^{7}$

It is possible that this is how the scribes of Ebla wrote the name of the city of Aššur. ${ }^{8}$ The geographical horizon of this text is vast and it includes cities probably far from Ebla and never mentioned before. All these people seem to want to meet the Eblaite vizier Ibbi-zikir in his march to Mari. It seems likely that the city of Ašuru is the city of Aššur, which at the end of the Early Bronze IV period was probably an important centre of commerce with Upper Mesopotamia and Syria.

- Gasur: If we consider $A$-šu-ru ${ }_{12}{ }^{k i}$ as referring to Aššur we must also consider it possible that the city written in the Ebla texts as Ga-su-lu ${ }^{k i}$ or $G a-s u-r u_{12}{ }^{k i}$ is Gasur, later Nuzi.

A city written Ga-šur ${ }_{x}\left(\right.$ HIxMAŠ $^{\mathrm{ki}}$ is mentioned often in the Ebla texts from the beginning of the archives to the end and is probably a town in the region between Mari and Ebla, perhaps in the region of Emar, as Bonechi suggested.9

But the town written as Ga-su-lu ${ }^{k i}$ or $\mathrm{Ga}$-su-ru ${ }_{12}{ }^{k i}$ could be Gasur of the Old Akkadian period.

A town named Ga-su-luki is mentioned in an "en-ma" text that will be published by P. Fronzaroli, 76.G.I99+I69+I75 rev. II 7, a difficult but interesting text written by vizier Ibbi-zikir to the king. Ibbi-zikir reports to the king some war affairs in which Nagar, Kiš and Armi are involved. Ibbi-zikir has to pay for provisions for the soldiers (guruš). It is quite possible that we are dealing with one of Ebla's last military campaigns, the campaign against Armi, in which Nagar and Kiš were allied with Ebla. ${ }^{\text {Io }}$ A mention of Gasur could be possible here.

Another text, 75.G.I945, written in the last years of the Ebla archives, records deliveries of sheep as offering to deities and for other purposes. At obv. XI II-2I: 6 udu kú $\mathrm{kas}_{4}-\mathrm{kas}_{4}$ $N a$-gàr ki 6 udu kú kas $_{4}$-kas $_{4}$ - Kiški 4 udu kú Ga-su-ru ${ }_{\text {I2 }}{ }^{k i}$; the sheep are given as food to messengers of Nagar, Kiš and to (messengers from?) Gasuru. In this context it is quite possible

6 Steinkeller I998, 75-98 proposes to identify Hamazi with the capital of the region of Subartu.

7 See Archi - Biga 2003, I8 and n. 54.

8 A writing $A$-šu-ú $r^{\mathrm{ki}}$ is attested in text 75.G.2278 of the same period, see Archi - Biga 2003, I8, n. 54.

9 See Bonechi I993, I53.

Io See Otto - Biga 20I0, 486. 
that it refers to Gasur. At the end of the life of the Eblaite kingdom a relationship with Aššur and Gasur is therefore possible.

In texts dating from the last years of the life of Ebla we can find attestations of both Gasur (written Ga-su-luki or Ga-su-ru ${ }_{\mathrm{r} 2}{ }^{\mathrm{ki}}$ and Ga-šur ${ }_{\mathrm{x}}\left(\mathrm{HIxMAŠS}^{\mathrm{ki}}\right)$, although it is difficult (if not impossible) to accept that scribes used different spellings of the same city in the same period.

- Nagar: Close and frequent political, diplomatic and commercial relationships between the capital city Nagar (Tell Brak), the surrounding region and the kingdom of Ebla are documented throughout the duration of the royal archives. ${ }^{\text {II }}$ From the Ebla texts it is possible to identify several names of cities under the political control of the major center of Nagar at the time of the Ebla royal archives; among them is Nabatium (Tell Beydar), identified by Sallaberger. ${ }^{12}$ To give another example, in the annual account of metal 75.G.2464, dated to year 3 of Ibrium's tenure as vizier, some deliveries of quantities of silver to towns of the region of Nagar, including Nabatium, are mentioned. ${ }^{\mathrm{I} 3}$ The silver is brought by the merchant Iram-malik; it is very probable that all these towns were part of the kingdom of Nagar following the itinerary of the merchant Iram-malik. ${ }^{\mathrm{I}}$

The city of Nagar and Hamazi were undoubtedly two important centres for the trade in BAR.AN-equids, valuable and very expensive animals arriving from the Iranian region. ${ }^{15}$ Veterinary experts who cared for these animals came from Nagar too. ${ }^{\mathrm{I} 6}$

Many centuries later, at the time of the kingdom of Mittani, the texts on caring for equids would be based on and use terminology relating to horses of an Indo-Iranian origin, thus demonstrating how both horses and the expertise used in domesticating and caring for them were imported from that region.

II For an early study on the long-running relationships between Nagar and Ebla see Archi I998, I-I5; Biga I998, I7-22; see also Eidem et al. 200I, IOI; of course, the complete history and evaluation of the relationships between Ebla and Nagar deserve a volume, and will be possible only when more complete documents are published. For Nagar see Oates et al. I997; Oates et al. 200I.

I2 Sallaberger - Ur 2004, 5I-7I.

I3 75.G.2464 obv. III 23-IV 21: 5 ma-na bar 6 : kù níg-ba Zú-gú-uš Na-gàr ki 30 (gín) bar 6 : kù Ga-ga-ba-anki 30 (gín)

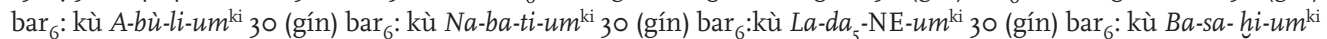

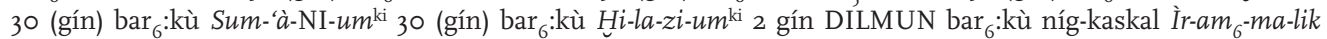
du-du Na-gàrki, "5 mina of silver for Zuguš of Nagar, 30 shekels of silver for (a person of) the city of Gagaban, 30 shekels of silver for (a person of) the city of Abulium, 30 shekels of silver for (a person of) the city of Nabatium, 30 shekels of silver for (a person of) the city of Ladaneum, 30 shekels of silver for (a person of) the city of Basahium, 30 shekels of silver for (a person of) the city of Sumanium, 30 shekels of silver for (a person of) the city of Hilazium, 2 shekels of silver as provision for the trip to Iram-malik who went to Nagar". It is quite probable that the merchant Iram-malik, well known from other texts, was sent by the Eblaite royal court for a commercial expedition to the region of Nagar. See also Archi 2005, 9-I9; the text where the business of Iram-malik is mentioned is possibly to be dated to the first years of vizier Ibrium as G.2464.

I4 In the Ebla texts there are certainly many itineraries followed by merchants and by the Eblaite army, but it remains difficult to attribute towns to different kingdoms and to identify them with modern tells.

I5 For these animals, now extinct, see Weber 2008, 499-5I6; Weber 2009, 29-40; Biga 2009a, 4I-56.

I6 See Biga 2006,85 . 
- Alalakh: The horizon of the Ebla kingdom included another city that had some importance at the time of Mittani kingdom; the city of Alalakh. Immediately after the death of Ibrium (or shortly before Ibrium died, but probably in the year of his death) there was a campaign against Alalakh which, subsequently, is mentioned more frequently in the texts. In conquering Alalakh, Ebla's political expansion reached the Mediterranean coast (even if Alalakh was not exactly on the coast). ${ }^{17}$

- Byblos: Byblos was an important city already closely related to Egypt from the $4^{\text {th }}$ millennium BC and well documented at the time of the Mittani kingdom and in the Amarna period. It was the big harbour where Egyptians came to buy precious wood, especially cedar wood and other products from Syria and from the East, for which Syria was an important trade centre. Identification of the city of DUlu, mentioned often in the Ebla texts, with Byblos was proposed by Pettinato and rejected later by some scholars..$^{18}$ In the archaeological excavations in Byblos many important and precious objects of pharaohs of the 3 rd, 4 th, 5 th and especially the 6th Dynasty were found. Pepi I, a contemporary of the last Eblaite king Išar-damu, is documented by several objects found in Byblos. ${ }^{19}$ It seems highly improbable that the kingdom of Ebla did not have any relationship with Byblos, which was surely very important at that time and not too far away. After studying the references to DUlu in the Ebla texts I recently concluded that there is no better candidate for Byblos in the Ebla texts than DUlu. A reading of the sign "DU" as gub is quite possible, and the absence of the dual (attested in the writing of Gubla in the second millennium) cannot be a big problem; in the Egyptian texts the name of Byblos is not a dual form. From DUlu (and also from Dugurasu as we shall see) linen textiles are often sent to Ebla. There is not another centre (apart from Dugurasu) from which linen textiles are always sent to Ebla. In the texts recording incoming quantities of goods to Eblaite palace storerooms (the so called "mu-DU" texts) linen textiles and objects made with precious stones of different colours are regularly sent to Ebla by DUlu and by Dugurasu. ${ }^{\circ}$ An inter-dynastic marriage between Tamurdasinu, a niece of vizier Ibrium and a son of the king of DUlu is documented in some texts. ${ }^{21}$

The recently discovered inscription of Iny, a functionary of three pharaohs of the 6th Dynasty, who was sent several times to Byblos and then to other Syrian cities to buy products such as lapislazuli, silver, tin and bitumen, demonstrates once again the great importance of Byblos during the time of the Ebla archives (see below, p. 98-99).

For all these reasons it is not impossible to identify DUlu with Byblos or with another town on the Syrian coast south of Byblos.

I7 For the texts relating to this conquest see Biga 20I0b, 47-48.

I8 Pettinato I983, I07-II8; Pettinato I986, 245-250. For the bibliography on DUlu see ARES II, 2IO-2II; Bonechi I993, II-I2; in both the books an identification of DUlu with Byblos is not excluded.

I9 See Scandone Matthiae I995, 37-48.

20 For some already published "mu-DU" texts registering the goods from DUlu see for ex. MEE II, I rev. VII 6-II; MEE XII, 3 (29), (3I), (32).

2I See ARET X I8, 74, 75, 94, 75.G.2329. 
I would like to emphasize the importance of the relationships between Egypt and Syria that already existed in the third millennium BC, many centuries before the relationships of the Mittani empire with Egypt. Archaeological evidence from Ebla itself and from other Syrian cities such as Byblos demonstrates the extremely close relationships between these two regions. The name of Egypt or of an Egyptian city has not been identified with certainty in the Ebla texts, but there is one good candidate: the town/region of Dugurasu. In the Ebla texts enormous quantities of gold are mentioned and used for different purposes. The origin of this gold is still unknown. We know that from the second millennium the main supplier of gold to all the regions of the ancient Near East was Egypt. Furthermore, several Egyptian objects and vases and two important Egyptian objects found in the Royal Palace G of Ebla prove that contact existed between the two kingdoms. ${ }^{22}$ There is no reason to suppose that this contact did not also exist during the period of the 4 th dynasty, when Pharaoh Chefren ruled. The presence of small blocks of lapislazuli, certainly from Afghanistan, in the royal palace $\mathrm{G}$ of Ebla proves that Ebla was a commercial centre for this stone; from the Ebla texts it is evident that the lapislazuli arrived in Ebla via Mari, which was another important stop on the long route of lapislazuli from Afghanistan to Syria and then to Egypt. It is well known how precious and commonly used by the Egyptian court and by the pharaohs lapislazuli was. Several Ebla texts mention quantities of lapislazuli bought in Mari by Eblaite merchants and lapislazuli sent as a gift by Mari's royal court to the Ebla king and queen. Lapislazuli was brought to Ebla over several years by different stewards (heads of a diplomatic delegation), sent as ambassadors of the Mari king to the Eblaite court. ${ }^{23}$ From Ebla the stone was taken to Byblos and to Egypt.

The Ebla texts prove that Ebla was also a commercial center for tin; there is evidence for tin being supplied to Ebla from Mari. The annual accounts of deliveries of metals mention large quantities of tin used (with copper) to produce different bronze objects, including many weapons.

The main sources of tin for Mesopotamia in the Bronze Age (and already in the third millennium) were in southwest Afghanistan. ${ }^{24}$ Mari, according to the Ebla texts, is a provider of tin and lapislazuli to Ebla.

22 See Scandone Matthiae I979, 33-43; Scandone Matthiae I98I, 99-I27.

23 Archi 1999, I47-I58.

24 See Lyonnet 2005, I9I-200. It has been proved that there existed a route used to bring tin from Tagikistan and Uzbekistan to Mesopotamia and then Syria as early as the third millennium. The texts of Mari of the second millennium prove that the Tigris valley and especially the Diyala valley were the routes through which tin arrived to Mari from the East, from the Iranian region. The transport of tin from Susa to Mari is well documented by the Mari texts; Ešnunna and Elam were providers of tin (and lapislazuli), see Joannès I99I, 67-76; Charpin - Ziegler 2003, 2I2. See also Amiet 2007, 64-87; Bushmakin 2007, I78-24I; Rossi Osmida 2007, I54-I77. 
There is now decisive proof of the existence of a direct trade relationship between Syria and Egypt at the time of the 6th Dynasty. In an Egyptian inscription recently assembled from different pieces belonging to collections in Japan, Spain and the US 25 there is the autobiography of Iny, an important Egyptian official who had a long life during the reigns of three pharaohs of the 6th Dynasty, including Pepi I and Pepi II. They all sent him to Byblos and then to a region that is certainly Syria to buy products from these regions. The products traded are: lapislazuli, tin, silver and bitumen. In the Ebla texts several gifts sent by the Eblaite court to different kingdoms are mentioned. Gifts of conspicuous quantities of lapislazuli, tin and silver from the Ebla court are sent only to the king of Dugurasu, a king who never went to Ebla to swear allegiance; from Dugurasu, objects of gold, linen textiles and quantities of precious stones of different colours and precious vases made of a stone that may be alabaster (the same objects that come from DUlu) are sent as a gift to the Ebla court. ${ }^{26}$ The products sent by Ebla to Dugurasu are identical with the products the functionary Iny went to buy in Syria. DUlu and Dugurasu are often mentioned together. People from DUlu come to Ebla with the news that the journey of some merchants to Dugurasu has ended successfully. In Dugurasu several functionaries are described as having relationships with Eblaite merchants and their names are clearly not Semitic and can be better explained as Egyptian names.

The journey to Dugurasu is a long one, and the messengers of Ebla receive several textiles for the journey and several textiles for their shoes and for headbands. All these elements prove that identifying Dugurasu with an Egyptian region or with an Egyptian city is quite possible. ${ }^{27}$

Pepi I was surely a contemporary of king Išar-damu of Ebla: the lid of an Egyptian alabaster vase marked with the cartouche of Pepi I and commemorating his Sed-festival was found in the royal palace $G$ of Ebla. It was very probably sent by Pepi I to the last king of Ebla on occasion of the ritual of renewal of kingship celebrated by king Išar-damu and his queen Tabur-damu. ${ }^{28}$

The close relationships between the Mittani kingdom and Egypt during the 2nd millenium were already in place one millennium before, during the EDIII b period, when the kingdom of Ebla had close and direct relationships, possibly with the pharaohs of the 4 th Dynasty, but certainly with those of the 6th Dynasty, the contemporaries of the Eblaite kings at the time of the royal archives.

25 See Marcolin 2010, 43-69.

26 For a "mu-DU" from Dugurasu to Ebla see for example MEE XII, 3 (30).

27 Identification of Dugurasu with Tukriš was proposed, see Pettinato I986, 284 (see also the comments in Bonechi I993, IIO) but the location of Tukriš east of Mesopotamia does not fit with the data of the Ebla texts; among several observations it would be very strange for the Ebla kingdom to send lapislazuli and tin to a kingdom which is closer than Ebla to the sources of these goods. See Biga, in press.

28 See Biga 20I0a, 37-39. 


\section{The cultural landscape: some observations}

Apparently, Hurrian names are not attested in the Ebla texts, but the name of the prince of Nagar, Ul-tum-HU.HU, who married the Eblaite princess Tagriš-damu in the last years of the Eblaite kingdom, remains difficult to explain as a Semitic name. ${ }^{29}$

Some deities already attested in the Eblaite pantheon end up as part of the Hurrian pantheon. When Eblaite studies first began, these deities were considered proof that Hurrians were already present in the Ebla period. Then it was demonstrated that deities such as Adamma and Ašdabil, $3^{\circ}$ well attested in the pantheon of the Mittani kingdom, were old deities of these regions, whose cult had survived for a long time before being absorbed into the Hurrian pantheon. Some scholars argued that Adamma and Ašdabil (with other divinities such as Kura, Adabal, Baliha, Ammarigu, etc.) were divinities of a substratum, $3^{\text {I }}$ but there is no evidence to support this statement. On the contrary, Adabal, a hypostasis of Adad, the great storm god of the Semitic region, is without doubt a Semitic god. And the fact that these deities are attested in the local calendar of Ebla (in which festivals for these deities are quoted) demonstrates in my opinion that these are in fact old Syrian deities.

The kings of the states who had close relationships with Ebla came to the temple of KUra to swear allegiance $3^{2}$ and from this it may be supposed that they were in some manner subordinate to Ebla. Otherwise, it would be difficult to understand why they traveled there. Why does the king of Ebla never swear allegiance to a king in another temple? We can be almost sure about this fact, because the king of Ebla never received fabrics for such a trip. Is KUra a divinity worshipped throughout at least northern Syria, or is he the dynastic divinity of a state more powerful than the others, which are, therefore, obliged to travel to Ebla?

It does not seem probable that Ebla was the strongest kingdom at the time; it was probably stronger than Emar, Ra'ak, Dub, Emar, Burman, Nirar, etc., but even the king of Mari comes to swear allegiance in the temple of KUra in Ebla, and Mari was, without doubt, stronger than Ebla. ${ }^{33}$ KUra was venerated by the people of Mari, too.

The fact that KUra was venerated in many kingdoms including Harran and Nagar of Upper Mesopotamia and by the kings of Mari suggests he was probably a transnational divinity venerated in all of Syria and Upper Mesopotamia, or it is possible that the god KUra represents an epithet of a major divinity.

29 For the two texts dealing with the marriage see Biga I998, I7-22; Biga 2009b/29, 37-40.

30 For the deities of Ebla see Pomponio - Xella I997.

3I See Archi i993, I0.

32 For the ceremony of swearing allegiance see Catagnoti I997, III-I37; Biga 2008, $302 \mathrm{f}$.

33 In an annual account of metals 75.G.2464, dated to Ibrium 3 year as vizier, after the quotation of several gifts to people of Mari, in obv III I3-22: 50 gín DILMUN bar 6 :kù nu $\mathrm{II}_{\mathrm{II}}$-za I dub lú nam-ku $\mathrm{Ib}_{5} \mathrm{la}^{\mathrm{ki}}$ wa Ma-riki é ${ }^{\mathrm{d}} \mathrm{KU}$-ra "50 shekels of silver for the decoration of the tablet of the oath of Ebla and Mari". 
Since the king of Nagar, perhaps unable to come to Ebla to renew his oath, goes, with other kings of the region, to the temple of Dagan in Tuttul, where vizier Ibrium arrives to represent the king of Ebla34, we might suppose that KUra was an epithet of Dagan, who was venerated in Ebla.

However, in the text ARET XIII I9 (I5)-(I6), relating to the relationships of the king of the city of 'Adu with Mari and Ebla, an oath for a pact of peace before the god KUra and the god Adad is mentioned.

The young king of Dub swears his allegiance to Ebla once in the temple of Adad. 35 The text quotes the temple of the god Adad, but does not state the name of the town where the temple is, and it is possible that the oath took place in a temple of this god in Ebla itself. In fact, a temple of Adad in Ebla itself is mentioned in some texts, for example in 75.G.2507 obv. III 5-7: é d 'À-da lú SA.ZA ${ }_{\mathrm{x}}^{\text {ki }}$.

Several texts mention an offering of sheep to the god Adad, venerated in the temple of KUra in Ebla. For example, in the long text of offerings of sheep to different deities, the offering of two sheep to the god Adad venerated in the temple of KUra is registered; 75.G.I945 obv. I I5-20: 2 udu d'À-da en nídba é dKU-ra. Several different deities are venerated in the temple of KUra and receive offerings; probably there were statues of these deities. It is improbable that KUra is an epithet of Adad; Adad was venerated in Aleppo and in Luban, Arugadu and Amadu as ' $A_{5}$-da-bal (Adad is lord). It seems difficult to admit so many hypostases of the god Adad.

The god Dagan gave to Sargon of Akkad Mari, Yarmuti and Ebla because he was the great god of the region from the Middle Euphrates to West Syria.

In conclusion it is possible that KUra is an epithet of one of the two principal gods of the region, Adad and Dagan. It is hard to decide which one, and it is difficult to interpret the name KUra. Possibly, with the end of the power of Ebla at the time of the archives the god KUra became less important and the other hypostasis increased in importance. This may explain the disappearance of the god KUra from the cult in the region.

The goddess Išhara ${ }^{36}$, the most important feminine deity of the Eblaite pantheon, was later highly venerated in the Hurrian pantheon. The queen mother Dusigu and, after her death, the queen Taburdamu regularly went on pilgrimages to several sanctuaries of the goddess Išhara. They especially visited three sanctuaries regularly, in a kind of religious itinerary: Zuramu, MaNE and Uguaš. In the town of MaNE37 in the Ebla kingdom, probably

34 75.G.2465 (annual account of metals of the time of Vizier Ibrium, year I6) obv. V I7-VI 8: 20 ma-na bar $_{6}$ : kù en Na-gàrki 5 ma-na bar 6 : kù níg-ba en-en lú áš-ti en Na-gàrki DU.DU nam-ku ${ }_{5}{ }^{\mathrm{d}} \mathrm{BE}$ Du-du-lu ${ }^{\mathrm{ki}}$, “2o mina of silver for the king of Nagar, 5 mina of silver gift for the kings who with the king of Nagar went to swear (the oath) in the temple of the Lord of Tuttul (Dagan)". For Dagan see also Otto 2006b, 242-268.

35 ARET I II (37). I would like to thank G. M. Schwartz, who reminded me of this text. At the time documented by the archives of Mari the oaths took place in temples of different deities and also in Adad temple, s. Charpin Ziegler 2003, IOI.

36 For Išhara see Prechel I996, Pomponio - Xella I997, 202-2I7.

37 See Ma'NE in Bonechi I993, 227-228; ARES II, 379-38I. 
not far from the Euphrates and the kingdom of Emar, there was an important sanctuary of the goddess Išhara. It is noteworthy that a place name NE-máki is documented in a legal document from Tall Beydar; $3^{8}$ it is possibly the same town. Several historical, religious and linguistic problems concern the presence of this deity in the Eblaite pantheon and the opinions of scholars differ greatly. 39

The Ebla texts document an interdynastic marriage between the Eblaite princess Tagriš-damu with the son of the king of Nagar. The princess arrives in Nagar to become queen of the country with her personal staff and also brings to Nagar her habits, her culture and her divinities. $4^{\circ}$

Centuries later, queen Puduhepa introduced Hurrian deities into the Hittite region;4I it is quite probable that an Eblaite princess introduced Syrian deities into the region of Upper Mesopotamia.

A common Semitic calendar was used in a vast region including Ebla, Mari, Gasur, Abu Salābīkh, Ešnunna during the EDIII period. This fact demonstrates beyond a doubt that these regions maintained close contacts and shared an extensive common cultural space. The scribes of Ebla dated all the texts of the small archives using the local calendar, but they dated all the texts of the great archive, dealing mostly with the external relationships of the Eblaite kingdom, with the month names of the common Semitic calendar. $4^{2}$ After the EDIII period this common Semitic calendar is not attested anymore.

\section{The fall of Ebla}

In reading all the texts relating to the late period of the life of the kingdom it becomes evident that Ebla had in its last years an enormous number of diplomatic relationships with many kingdoms. In some textile texts like 75.G.2247 (should be placed chronologically after Ibbi-zikir's Ioth year as vizier) the vast geographical horizon is surprising. Even the tablets themselves are large; these are the biggest tablets regarding monthly deliveries of textiles, and they have many lists of cities, perhaps following some kind of itinerary.

Despite its many victorious wars and numerous allies, Ebla itself was conquered, sacked and burned.

There are different theories regarding the destruction of Ebla. Archi - Biga proposed attributing its destruction to Mari; 43 this proposition was accepted by some scholars, for

38 Ismail et al. I996, I4I, text 35 obv. V 2.

39 Pomponio - Xella I997, 214-217.

40 For this marriage see Biga I998, I7-22; Biga 2009b/29, 37-40 and n.I.

4I See Popko I995, 97. II8. I5I.

42 See Cohen I993, 25-36; Biga 200I, 4IIf.

43 Archi - Biga 2003, 29-35. 
example by Sallaberger 44 and rejected by others such as Matthiae ${ }^{45}$ who sees Sargon of Akkad as responsible for the destruction of Ebla. Was Ebla destroyed by Sargon, by Mari, or by another enemy? It is hard to be certain about this. Probably the last campaign of Ebla, allied with Nagar, was against Armi. We know from many texts (ARET IX) that men from Armi were at Ebla, but we do not know why. Is it possible to suppose that there were internal disorders and troubles (caused by the men of Armi?) and an attack by Armi itself? Can it be argued that, with the destruction of the city and the end of the dynasty in power, the region was taken over by Armi/Armanum, a city that Naram-Sin claims in his inscription to have conquered?

The only certainties we have are: the military campaign of Ebla against Mari that probably weakened both kingdoms. Given that Vizier Ibbi-zikir went to war every year, it is obvious that the cost of these wars was high both in terms of weapons for the army and in terms of human life lost in battle, and perhaps as a result of leaving the city unprotected. Probably the conflict with Mari on the battlefields around Terqa was concluded without a real victor because Ibbi-zikir did not have the strength to reach and take Mari, and Mari had to sue for peace.

Ebla brought together an enormous group of allies against Mari. From the period of the military campaign against Mari and immediately after, the monthly accounts of deliveries of fabrics from Ebla to the closest allies mention dozens of toponyms, names of towns, small kingdoms under the political control of Ebla, but probably also other kingdoms, perhaps in the regions that the Eblaite army passed through.

Apparently many cities were interested in supporting Ebla against Mari.

As Matthiae pointed out, "the collapse of Ebla was not preceded by any economic, social, cultural, military, political crisis". ${ }^{6}$ For several reasons we cannot know exactly how many years after the military campaign against Mari Ebla itself collapsed.

The three or four year period that Archi and I accepted in our article in JCS 2003 is not certain. Too many monthly accounts of deliveries of fabrics still need to be completed with textual joins and to be put in chronological order. And we do not know if, for example, the city of Ebla was under siege for the years in which no tablets were written of course.

44 Sallaberger 2007, 42I-423.

45 Matthiae 2009a, 60-62; see p. 60 and n. 52 for the three different positions. J.-M. Durand proposed another solution at a conference in Brussels and it will be published soon. See Matthiae 2009 a, 43-62 for a complete discussion of all the aspects of the destruction of Ebla.

46 Matthiae 2009a, 6I. 


\section{Syria and Upper Mesopotamia from the fall of Ebla to the end of EB IVB}

The fall of Ebla and the quite radical destruction of the town, including the temples, 47 spelled the end of the Ebla dynasty's power. It is not yet known if a major centre replaced Ebla in the region, if such a centre existed. Surely the town of Aleppo increased in size and influence, and the temple of EB IVB was important, as was demonstrated by recent excavations.

According to Matthiae “The town was not apparently reconstructed immediately after, and particularly the ancient palace structures could not be recovered: the ruins of the Royal Palace $G$ remained buried under the collapses of the fire, and there were no traces of reconstruction in the following period. The town of the following Early Bronze IVB period was probably smaller in size, perhaps mostly located in the north part of the ancient glorious settlement." 48

The archaeological data from the surveys in the region around Ebla, Tall Afis, Tall Tuqan show that there are numerous centers presenting a EB IV B phase and that there was no demographic crisis: possibly all the cities and villages quoted in the Ebla texts survived, urban life continued and no deurbanization took place.

Archaeological and philological evidence from Mari demonstrates that Ebla was conquered some years (around Io years?) before Mari. Nagar, the major site of the Upper Khabur region, suffered destruction at the same time as Ebla and was then occupied by NaramSin, as proved by royal inscriptions and by archaeological data. Tall Beydar was partially abandoned at almost the same period as Ebla, but was reoccupied some decades later. The palace of Tuttul burned at around the same time as that of Ebla, but occupation at Tuttul continued. It is extremely difficult to synchronize all these destructive events. Tall Mozan (ancient Urkeš) in the Upper Khabur became an important urban center with a Hurrian ruling family49. It is difficult to write the history of Syria and Upper Mesopotamia in EB IVB because of the scarcity of written sources from these regions. And contemporary administrative texts from Mesopotamia often have a limited horizon or refer to only a few major centres of this region. The royal inscriptions of course must be used with great caution when writing history. $5^{\circ}$

From the archaeological data, taking a long view of 1500 years for a number of sites in Syria, it has been demonstrated ${ }^{1}$ that "in Northern Inland Syria the available evidence from

47 Matthiae 2009b, 677-730.

48 Matthiae 2009a, 59.

49 Buccellati 2002, I27-I33; Salvini I998, 99-II5.

50 For the reconstruction of the history of Upper Mesopotamia and Syria of this period see the recent and important article of Sallaberger 2007, 4I7-456 with previous bibliography; see also Chavalas - Hayes I992; for the region of Upper Mesopotamia see also Lyonnet 2009, I79-200. For the destruction of Nagar, Mari and Ebla see Lebeau 20I2, 30I-322.

5 I Schwartz 2007, 49.55. 
ca. 3000-I500 BC suggests occupational continuity, with the exception of disjunctures in the late third Millennium and in the mid-second Millennium". And for the region of the Upper Khabur it was noted that "the late EB is the major period of disjuncture" and "sites such as Tall Beydar, Leilan and Hamoukar suffer trauma by the end of the period". But "there are also several sites without evidence of significant disruption in their EB-MB sequence".

In conclusion, in the area of Syria and Upper Mesopotamia in the EB IV B (2300-2000), despite vicissitudes of prosperity and weakness, there probably was not a dramatic reduction in population or a significant level of deurbanization.

\section{Conclusions}

The archives of Ebla, the texts from Tall Beydar and Tall Mozan, are the only available sources for reconstructing the space in the middle of the third millennium (2500-2300 BC) later inherited by the Mittani kingdom. But the archives of Ebla especially allow us to reconstruct the political and cultural landscape of Syria and Upper Mesopotamia, territories where the state of Mittani ruled from the i6th century BC.

Several of the cities that will be important at the time of Mittani empire were already important cities at the time of the Eblaite kingdom, and their life continued despite vicissitudes of prosperity and weakness.

Some scholars used to consider Syria and Upper Mesopotamia as a periphery of Mesopotamia, but the archaeological and written evidence has made it increasingly clear that in the third millennium BC Syria and Upper Mesopotamia were in fact already a crossroad of important long trade routes coming from the Middle East and reaching the Mediterranean (Byblos) and Egypt. Cities such as Mari, Nagar, Hamazi, Harran, Byblos, and Ebla were important stops along these commercial routes. Some of them continued to be important centres much later, at the time of Mittani empire. Other cities such as Karkemiš, Alalakh, Emar, Tall Bazi (possibly Armi of the Ebla period), Umm el-Marra (possibly Dub of the Ebla period), Assur and Gasur, attested also at the period of the Mittani kingdom, were already important at the time of Ebla.

Some texts from Tall Mozan (ancient Urkeš) prove that Hurrian people were already present at the time of the Ebla archives.

It is more difficult to write the history of Syria and Upper Mesopotamia in EB IVB (2300-2000 BC) because of the scarcity of written sources from these regions. And contemporary administrative texts from Mesopotamia often have a limited horizon or refer to only a few major centres of this region. The royal inscriptions must of course be used with great caution when writing history. But it has been shown archaeologically that urban culture continued in these regions and that there was no passage from urban culture to nomadism, as some scholars have argued. 
In the area of Syria and Upper Mesopotamia in the EB IV B (2300-2000), despite vicissitudes of prosperity and weakness, there probably was not a dramatic reduction in population or a significant level of deurbanization.

\section{Bibliography}

Amiet 2007

P. Amiet, L'âge des échanges Inter-Iraniens, 3500-I700 avant J. C., in: G. Ligabue - G. Rossi Osmida (eds.), Sulla via delle oasi. Tesori dell'Oriente antico (Trebaseleghe 2007) 64-87.

\section{Archi 1993}

A. Archi, How a Pantheon forms, in: B. Janowski et al. (eds.), Religionsgeschichtliche Beziehungen zwischen Kleinasien, Nordsyrien und dem Alten Testament, OBO I29, I993, I-I8.

\section{Archi 1998}

A. Archi, The Regional State of Nagar According to the Texts of Ebla, in: M. Lebeau (ed.), About Subartu. Studies Devoted to Upper Mesopotamia, vol. 2: Culture, Society, Image, Subartu 4/2 (Turnhout I998) I-I5.

\section{Archi 1999}

A. Archi, The Steward and his Jar, Iraq 6I, I999, I47-I58.

\section{Archi 2005}

A. Archi, The Business of Mr. Iram-malik, in: L. Kogan et al. (eds.), Memoriae Igor M. Diakonoff (Winona Lake 2005) 9-19.

Archi - Biga 2003

A. Archi - M. G. Biga, A Victory over Mari and the Fall of Ebla, JCS 55, 2003, I-44.

\section{Biga 1998}

M. G. Biga, The Marriage of Eblaite Princess Tagriš-damu with a Son of Nagar's King, in: M. Lebeau (ed.), About Subartu. Studies Devoted to Upper Mesopotamia, vol. 2: Culture, Society, Image, Subartu 4/2 (Turnhout I998) I7-22.

Biga 200I

M. G. Biga, Il computo del tempo, in: M. Liverani et al. (eds.), Storia della Scienza, I/3: Il Vicino Oriente antico (Roma 200I) 409-4I6.

\section{Biga 2003}

M. G. Biga, Las guerras de Ebla, in: M. Alonso Baquer et al. (eds.), La Guerra en Oriente Próximo y Egipto (Madrid 2003) 79-87.

Biga 2006

M. G. Biga, (Foreign) Veterinarians at Ebla, N.A.B.U. 2006/84, 85 .

Biga 2008

M. G. Biga, Au-delà des frontières: guerre et diplomatie à Ebla, Orientalia 77, 2008, 289-334. 


\section{Biga 2009a}

M. G. Biga, On Equids, other Animals and Veterinarians in the Texts of the Ebla's Archives (Syria, $3^{\text {rd }}$ Millennium B.C., XXIV Cent. B.C.), in: D. Tabbaa - M. Al Hayek (eds.), Animals in the Old Syrian Civilizations (Hama 2009) 4I-56.

\section{Biga 2009b}

M. G. Biga, ARET I 3+ARET XII I46, ARET I 7+ARET XII 934 and Other Recent Joins of the Ebla Monthly Accounts of Deliveries of Textiles, in: N.A.B.U. 2009/29, 37-40.

\section{Biga 20I0a}

M. G. Biga, Tra Menfi e Ebla, in: L'Egitto tra storia e letteratura, Serekh 5 (Torino 20I0) 23-40.

\section{Biga 2orob}

M. G. Biga, War and Peace in the Kingdom of Ebla (24 ${ }^{\text {th }}$ Century B.C.) in the First Years of Vizier Ibbi-zikir under the Reign of the Last King Išar-damu, in: M. G. Biga - M. Liverani (eds.), ana turri gimilli. Studi dedicati al Padre Werner R. Mayer SJ da amici ed allievi (Roma 2010) 39-57.

\section{Biga 2013}

M.G.Biga, Defining the Chora of Ebla. A Textual Perspective, in: P. Matthiae - N. Marchetti (eds.), Ebla and its Landscape. Early State Formation in the Ancient Near East (Walnut Creek 2013), 259-267.

\section{Biga (in print)}

M. G. Biga, The Relationships between the Kingdom of Ebla and Egypt According to the Texts of the Royal Archives of Ebla (XXIV Cent. B.C.) (in print).

\section{Biga-Capomacchia 2012 (in print)}

M. G. Biga - A. M. G. Capomacchia, I testi di Ebla di ARET XI: una rilettura alla luce dei testi paralleli, RA IO2 (20I2), Melanges P. Matthiae, in print.

\section{Bonechi 1993}

M. Bonechi, Répertorie Géographique des Texts Cunéiformes I2/I: I nomi geografici dei testi di Ebla (Wiesbaden I993).

\section{Buccellati 2002}

G. Buccellati - M. Kelly Buccellati, Mozan/Urkesh: A New Capital in the Northern Diezireh, in: M. Al-Maqdissi et al. (eds.), The Syrian Jezira: Cultural Heritage and Interrelations: Proceedings of the International Conference held in Deir ez-Zor, April 22nd-25th 1996 (Damascus 2002), I27-I33.

\section{Bushmakin 2007}

A. G. Bushmakin, Minerals and Metals of Bactria and Margiana, in: G. Ligabue - G. Rossi Osmida (eds.), Sulla via delle oasi, Tesori dell'Oriente antico (Trebaseleghe 2007) I78-24I.

\section{Catagnoti 1997}

A. Catagnoti, Sul lessico dei giuramenti a Ebla: nam-ku, in: Quaderni di Semitistica I9, Miscellanea Eblaitica 4 (Firenze I997) III-I37.

Charpin - Ziegler 2003

D. Charpin - N. Ziegler, Mari et le Proche-Orient à l'époque amorrite. Essai d'histoire politique (Paris 2003). 


\section{Chavalas - Hayes 1992}

M. W. Chavalas - J. L. Hayes (eds.), New Horizons in the Study of Ancient Syria, Bibliotheca Mesopotamica 25 (Malibu I992).

\section{Cohen 1992}

M. Cohen, The Cultic Calendars of the Ancient Near East (Bethesda I992).

\section{Eidem et al. 200I}

J. Eidem, The Third Millennium Inscriptions, in: D. Oates - J. Oates - H. McDonald (eds.), Excavations at Tell Brak, vol. 2: Nagar in the Third Millennium B.C. (London 200I), Chapter 3, 99-I20.

\section{Ismail et al. 1996}

F. Ismail et al., Administrative Documents from Tell Beydar, Subartu 2 (Turnhout I996).

\section{Lebeau 2012}

M. Lebeau, Dating the Destructions of Ebla, Mari and Nagar from Radiocarbon with References to Egypt, Combined with Stratigraphy and Historical Data, in: H. Baker et al. (eds.), Stories of long ago. Fs M. D. Roaf, AOAT 397, 30I-322.

\section{Joannès 1991}

F. Joannès, L'étain, de l'Elam à Mari, in: L. De Meier - H. Gasche (eds.), Mesopotamie et Elam. Actes de la XXXVIième Rencontre Assyriologique International, Gand, IO-I4 juillet I989 (Ghent I99I) 67-76.

\section{Ligabue - Rossi Osmida 2007}

G. Ligabue - G. Rossi Osmida (eds.), Sulla via delle oasi, Tesori dell'Oriente antico (Trebaseleghe 2007).

\section{Lyonnet 2005}

B. Lyonnet, Another Possible Interpretation of the Bactro-Margiana Culture (BMAC) of Central Asia: The Tin Trade, in: C. Jarrige - V. Lefevre (eds.), South Asian Archaeology 200I, vol. I: Prehistory (Paris 2005) I9I-200.

\section{Lyonnet 2009}

B. Lyonnet, Who lived in the Third-Millennium "Round Cities" of Northern Syria?, in: J. Szuchman (ed.), Nomads, Tribes, and the State in the Ancient Near East. Cross-Disciplinary Perspectives (Chicago 2009) I79-200.

\section{Marcolin 2010}

M. Marcolin, Una nuova biografia egiziana della VI dinastia con iscrizioni storiche e geografiche, Atti della Accademia delle Scienze di Torino. Classe di Scienze Morali, Storiche e Filologiche I44, 2010, 43-69.

\section{Matthiae 2009a}

P. Matthiae, Crisis and Collapse: Similarity and Diversity in the three Destructions of Ebla from EB IVA to MBII, Scienze dell'Antichità I5, 2009, 43-83.

\section{Matthiae 2009b}

P. Matthiae, Il tempio della roccia ad Ebla: la residenza mitica del dio Kura e la fondazione della città proto siriana, Scienze dell'Antichità 15,2009 , 677-730. 
Oates et al. 1997

D. Oates - J. Oates - H. Mc Donald, Excavations at Tell Brak, vol. I: The Mitanni and Old Babylonian Periods (London I997).

Oates et al. 200I

D. Oates - J. Oates - H. Mc Donald, Excavations at Tell Brak, vol. 2: Nagar in the Third Millennium B.C. (London 200I).

Otto 2006a

A. Otto, Archaeological Perspectives in the Location of Naram-Sin's Armanum, JCS 58 , $2006, \mathrm{I}-26$.

Otto 2006b

A. Otto, Das Oberhaupt des westsemitischen Pantheons ohne Abbild? Überlegungen zur Darstellung des Gottes Dagan, ZA 96, 2006, 242-268.

Otto - Biga 2010

A. Otto - M. G. Biga, Thoughts about the Identification of Tall Bazi with Armi of the Ebla Texts, in: P. Matthiae - F. Pinnock - L.Nigro - N. Marchetti (eds.), Proceedings of the $\sigma^{\text {th }}$ International Congress on the Archaeology of the Ancient Near East, vol. I (Wiesbaden 20I0) 48I-494.

\section{Pettinato 1983}

G. Pettinato, Le città fenicie e Byblos in particolare nella documentazione epigrafica di Ebla, in: S. F. Bondì (ed.), Atti del primo Congresso di Studi Fenici e Punici (Roma I983) I07-II8.

\section{Pettinato 1986}

G. Pettinato, Ebla. Nuovi orizzonti della storia (Milano I986).

\section{Pinnock 1988}

F. Pinnock, Observations on the Trade of Lapis Lazuli in the Third Millennium BC, in: H. Waetzoldt - H. Hauptmann (eds.), Wirtschaft und Gesellschaft von Ebla (Heidelberg I988) I07-IIO.

\section{Pinnock 2006}

F. Pinnock, The Raw Lapis Lazuli in the Royal Palace G of Ebla: New Evidence from the Annexes of the Throne Room, in: M. E. Alberti - E. Ascalone - L. Peyronel (eds.), Proceedings of the International Colloquium: Weights in Context. Weighing Systems of Eastern Mediterranean, 22-24 November 2004 Rom, Istituto Italiano di Numismatica, Studi e Materiali I3 (Rom 2006) 347-357.

Pomponio - Xella 1997

F. Pomponio - P. Xella, Les dieux d'Ebla (Münster I997).

\section{Popko 1995}

M. Popko, Religions of Asia Minor (Warsaw 1995).

Prechel 1996

D. Prechel, Die Göttin Išhara (Münster I996).

\section{Rossi Osmida 2007}

G. Rossi Osmida, Margiana e Via delle Oasi, in: G. Ligabue - G. Rossi Osmida (eds.), Sulla via delle oasi, Tesori dell'Oriente antico (Trebaseleghe 2007) I54-I77. 


\section{Sallaberger 2007}

W. Sallaberger, From Urban Culture to Nomadism; a History of Upper Mesopotamia in the Late Third Millennium, in: C. Kuzucuoğlu - C. Marro (eds.), Sociétés humaines et changement climatiques à la fin du troisième millénaire: une crise a-t-elle eu lieu en Haute Mésopotamie? (Paris 2007) 4I7-456.

\section{Sallaberger - Ur 2004}

W. Sallaberger - J. Ur, Tell Beydar/Nabada in its Regional Setting, in: L. Milano - W. Sallaberger - P. Talon - K. van Lerberghe (eds.), Third Millennium Cuneiform Texts from Tell Beydar (Seasons I996-2002), Subartu I2 (Turnhout 2004), 5I-7I.

\section{Salvini 1998}

M. Salvini, The Earliest Evidence of the Hurrians before the Formation of the Reign of Mittani, in: G. Buccellati - M. Kelly-Buccellati (eds.), Urkesh and the Hurrians, Studies in Honor of Lloyd Cotsen, Urkesh/Mozan Studies 3, Bibliotheca Mesopotamica 26 (Malibu I998) 99-II5.

\section{Scandone Matthiae I979}

G. Scandone Matthiae, Vasi iscritti di Chefren e Pepi I nel Palazzo Reale G di Ebla, in: Studi Eblaiti I, I979, 33-43.

\section{Scandone Matthiae i98I}

G. Scandone Matthiae, I vasi egiziani in pietra del Palazzo Reale G, in: Studi Eblaiti 4, I98I, 99-I27.

\section{Scandone Matthiae 1995}

G. Scandone Matthiae, La cultura egizia a Biblo attraverso le testimonianze materiali, in: P. Xella (ed.), Biblo. Una città e la sua cultura (Roma I995) 37-48.

\section{Scandone Matthiae 1997}

G. Scandone Mattiae, The Relations between Ebla and Egypt, in: E. Oren (ed.), The Hyksos: New Historical and Archaeological Perspective (Philadelphia I997) 4I5-427.

\section{Schwartz 2007}

G. M. Schwartz, Taking the Long View on Collapse: a Syrian Perspective, in: C. Kuzucuoÿlu C. Marro (eds.), Sociétés humaines et changement climatiques à la fin du troisième millénaire: une crise a-t-elle eu lieu en Haute Mésopotamie? (Paris 2007) 45-67.

\section{Steinkeller 1998}

P. Steinkeller, The Historical Background of Urkesh and the Hurrian Beginnings in Northern Mesopotamia, in: G. Buccellati - M. Kelly-Buccellati (eds.), Urkesh and the Hurrians, Studies in Honor of Lloyd Cotsen, Urkesh/Mozan Studies 3, Bibliotheca Mesopotamica 26 (Malibu I998) 75-98.

\section{Weber 2008}

J. Weber, Elite Equids: Redefining Equid Burials of the Mid-to Late 3rd Millennium BC from Umm el-Marra, Syria, in: E. Vila et al. (eds.), Archaeozoology of the Near East VIII, 499-516.

\section{Weber 2009}

J. Weber, New Research on a "Royal" Animal of Ancient Syria, in: D. Tabbaa - M. Al Hayek (eds.), Animals in the Old Syrian Civilizations (Hama 2009) 29-40. 